Iowa has every reason to be very proud of one of her sons. I refer to Admiral Frank Friday Fletcher. Editorials in the great New York dailies mentioned his services in the highest terms, and President Wilson complimented him personally in the White House. I refer, of course, to Admiral Fletcher's exceptionally wise conduct of affairs at Vera Cruz. He has now received the greatest reward that can be given to any naval officer in times of peace, commander-in-chief of the North Atlantic fleet.

Sincerely yours, .

Charges A. Chanke. U. S. N.

\title{
NEW STEAM MILL AT BLOOMINGTON (NOW MUSCATINE)
}

Bennett's magnificent steam mill is now up and inclosed. It is 77 feet high in front and 67 in the rear. The chimney is 87 feet high and contains 90 thousand brick. The steam boilers are the finest we recollect ever having seen. Altogether it forms an imposing and splendid structure, built to stand for ages, we should think, and is an ornament to the town. The main building is 85 by 50 feet, and contains over 330,000 brick. 'The basement is of solid limestone masonry, with the foundation sunk eight fect below the ground floor. The mill is designed to manufacture 300 barrels of flour per day, consuming more than 1400 bushels of wheat daily.

This mill will prevent the shipment of wheat from this point, until it is manufactured into flour-a great saving to the country. This is one exemplification of the utility of this kind of improvement. The concern will employ, constantly, a large laboring force, and prevent the payment of freight upon the offal and save it to be consumed, in the town, and country around. The feed it will make for cows, pigs, horses and the like, will be of great. utility and usefulness to the citizens. Suecess attend the-enterprise.-The Bloomington Herald, Bloomington, Iowa, Saturday, November 18, 1848. (In the newspaper collection of the Historical, Memorial and Art Department.) 
Copyright of Annals of Iowa is the property of State of Iowa, by \& through the State Historical Society of Iowa and its content may not be copied or emailed to multiple sites or posted to a listserv without the copyright holder's express written permission. However, users may print, download, or email articles for individual use. 